\title{
MODEL PEMBELAJARAN BAHASA INGGRIS \\ DI PONPES TA'MIRUL ISLAM SURAKARTA
}

\author{
Faizal Risdianto \\ IAIN Salatiga \\ faizrisd@gmail.com
}

\begin{abstract}
This research applies descriptive qualitative method aiming at knowing the format and model as well as the motivating and resisting power of English learning at Ta'mirul Islam Male Boarding School Surakarta. From observations and interviews, it is found that there is as direct learning strategy using teacher-centered approach. This learning strategy is even more detailed by the 'army method' learning model which emphasizes high discipline and teacher authority as well as direct method which stresses on the teacher instructions. The learning model of the school follows behavioristic patterns that emphasizes on customization in language skills. It is combined with army method patterns that treat students with rewards and punishments. The motivating power of the English learning process at the boarding house is the availability of facilities, biah lughowiyah or the environment that supports the students to be able to speak and write in English. Meanwhile, the ressisting factor is the ignorance of most students toward the punishments given by the authority.
\end{abstract}

Keywords: learning, study, Direct Method, Ta'mirul Islam

\section{Pendahuluan}

Pesantren sebagai lembaga pendidikan Islami terpenting adalah sebuah pendidikan tradisional yang para siswanya tinggal bersama dan belajar di bawah bimbingan guru yang lebih dikenal dengan sebutan"kiai" dan mempunyai asrama untuk tempat menginap santri.Santri tersebut berada dalam kompleks yang juga menyediakan masjid untuk beribadah, ruang untuk belajar, dan kegiatan keagamaan lainnya.Kompleks ini biasanya dikelilingi oleh tembok untuk dapat mengawasi keluar masuknya para santri sesuai dengan peraturan yang berlaku (Dhofier 1983, 18).

Pondok Pesantren merupakan dua istilah yang menunjukkan satu pengertian.Pesantren menurut pengertian dasarnya adalah tempat belajar para santri, sedangkan pondok berarti rumah atau tempat tinggal sederhana terbuat dari bambu.Di samping itu, kata pondok mungkin berasal dari Bahasa Arab funduq yang berarti asrama atau hotel. Di Jawa termasuk Sunda dan Madura umumnya digunakan istilah pondok dan pesantren, sedang di Aceh dikenal dengan Istilah dayah atau rangkang atau menuasa, sedangkan di Minangkabau disebut surau. (Madjid 1997, 5)

Namun demikian, meskipun pesantren memiliki banyak kelebihan bukan berarti tidak mempunyai kelemahan dan kekurangan. Menurut Amien Rais (1987, 24) ada beberapa kelemahan pesantren yang perlu segera dibenahi antara lain : (1) alumni pesantren umumnya mempunyai pikiran yang sempit dan tidak percaya diri ketika bersentuhan dengan kehidupan riil di masyarakat yang selalu berkembang sejalan dengan kemajuan ilmu pengetahuan dan teknologi; (2) pesantren pada umumnya tidak melengkapi para santrinya dengan berbagai skill yang patut diandalkan untuk menghadapi tantangan hidup di zaman modern ini; (3) pesantren umumnya tertutup untuk menerima perubahan sehingga amat susah untuk mengikuti perkembangan yang terus bergerak. 
Untuk itu perlu adanya perbaikan dengan melakukan rekonstruksi terhadap model pendidikan yang ada. Perbaikan yang perlu dibuat ialah kesadaran dalam mengadakan perubahan terhadap pendidikan pesantren, untuk memperbaharui atau modernisasi pendidikan Islam, akhirnya banyak pondok pesantren yang mulai berbenah dan memodernisasi sistem pendidikan, manajemen dan kurikulumnya, terutama dengan mengenalkan ilmuilmu umum seperti mengajarkan Bahasa asing seperti Bahasa Inggris kepada santri.

Fakta diatas merupakan suatu bukti bahwa pesantren dapat melakukan pembaruan pendidikannya. Perubahan dan dinamika yang terjadi dalam pesantren sampai saat ini menunjukkan hasil yang menggembirakan. Sebagian pesantren mampu bersaing dengan sekolah negeri baik di bawah Kemendiknas maupun Kemenag. Sebagian para santri menguasai dan punya prestasi yang lebih unggul dari siswa-siswi di sekolah yang bukan pesantren. Mereka mampu bersaing dalam mata pelajaran umum dan agama. Dan bahkan beberapa pesantren senantiasa menyelenggarakan pendidikan, pembinaan dan pengembangan santri untuk keunggulan dan kesempurnaan melalui program pendidikan yang utuh dan terpadu. Salah satunya adalah Pondok Pesantren Ta'mirul Islam Surakarta yang beralamatkan di Jl. KH.Samanhudi No. 03, Tegalsari, Bumi Laweyan, Surakarta.

Pendidikan Pondok Pesantren Ta'mirul Islam menerapkan sistem pendidikan modern sebagaimana lembaga pendidikan sekolah yang menerapkan sistem asrama (Islamic Boarding School). Pondok ini memiliki motto Iso Ngaji Lan Ora Kalah Karo Sekolah Negeri, tidak heran jika kurikulum pesantren didesain dengan meng-kolaborasi-kan antara ilmu-ilmu agama dan ilmu-ilmu umum secara seimbang. Salah satu karakteristik modernisasi Pondok Pesantren Ta'mirul Islam ditandai dengan digunakannya bahasa Arab dan bahasa Inggris sebagai bahasa pengantar dalam kegiatan keseharian di Pondok Pesantren.

Berangkat dari permasalahan di atas dan karena keterbatasan waktu dan terlalu luasnya cakupan persoalan maka persoalan yang dapat dirumuskan dalam penelitian ini yaitu:

1. Bagaimanakah bentuk pembelajaran Bahasa Inggris di Pondok Pesantren Ta'mirul Islam Surakarta?

2. Seperti apakah model belajar santri ketika belajar Bahasa Inggris di Pondok Pesantren Ta'mirul Islam Surakarta?

3. Apakah yang menjadi daya pendorong dan penghambat dalam proses belajar Bahasa Inggris di Pondok Pesantren Ta'mirul Islam Surakarta?

\section{LANDASAN TEORI}

Strategi pembelajaran menurut Kemp (1995, 21) ialah suatu kegiatan pembelajaran yang harus dilaksanakan oleh guru dan siswa agar tujuan pembelajaran dapat dicapai secara efektif dan efisien. Usaha menerapkan rencana pembelajaran yang telah disusun dalam kegiatan nyata agar tujuan yang telah disusun dapat tercapai secara optimal, maka diperlukan suatu metode yang digunakan untuk merealisasikan strategi yang telah ditetapkan.

Dengan demikian, bisa terjadi satu strategi pembelajaran menggunakan beberapa metode. Misalnya, untuk melaksanakan strategi ekspositori bisa digunakan metode ceramah sekaligus metode Tanya-jawab atau bahkan diskusi dengan memanfaatkan sumber daya yang tersedia termasuk menggunakan media pembelajaran. Oleh sebab itu, strategi berbeda dengan metode. Strategi menunjukkan pada sebuah perencanaan untuk mencapai 
suatu tujuan, sedangkan metode adalah cara yang dapat digunakan untuk melaksanakan strategi. Dengan kata lain, strategi adalah a plan of operation achieving something; sedangkan metode adalah a way in achieving something.

Pendekatan dapat diartikan sebagai titik tolak atau sudut pandang kita terhadap proses pembelajaran. Istilah pendekatan merujuk kepada pandangan tentang terjadinya suatu proses yang sifatnya masih sangat umum. Roy Kellen (1998, 31) mencatat bahwa terdapat dua pendekatan dalam pembelajaran, yaitu pendekatan yang berpusat pada guru (teacher-centered approaches) dan pendekatan yang berpusat pada siswa (student-centered Approaches).Pendekatan yang berpusat pada guru menurunkan strategi pembelajaran langsung (Direct Instruction), pembelajaran deduktif atau pembelajaran ekspositori. Sedangkan, pendekatan pembelajaran yang berpusatpadasiswa menurunkan strategi pembelajaran inkuiri dan diskoveri serta pembelajaran induktif.

Sedangkan model-model pembelajaran sendiri biasanya disusun berdasarkan berbagai prinsip atau teori pengetahuan. Para ahli menyusun model pembelajaran berdasarkan prinsip-prinsip pembelajaran, teoriteori psikologis, sosiologis, analisis system, atau teori-teori lain yang mendukung (Joyce \& Weil, 1980).

\section{Faktor-faktor yang Mempengaruhi Belajar}

Secara global, faktor-faktor yang mempengaruhi belajar siswa dapat kita bedakan menjadi tiga macam, yakni:

1. Faktor internal (faktor dari dalam siswa), keadaan/kondisi jasmani dan rohani siswa.

2. Faktor ekstenal (faktor dari luar siswa), yakni kondisi lingkungan di sekitar siswa.

Faktor-faktor di atas dalam banyak hal sering saling berkaitan dan mempengaruhi satu sama lain. Seorang siswa yang bersikap conserving terhadap ilmu pengetahuan atau bermotif ekstrinsik (faktor eksternal) umpamanya, biasanya cenderung mengambil pendekatan belajar yang sederhana dan tidak mendalam. Sebaliknya, seorang siswa yang berinteligensi tinggi (faktor internal) dan mendapatkan dorongan positif dari orangtuanya (faktor eksternal), mungkin akan memilih pendekatan belajar yang mementingkan kualitas hasil pembelajaran. Jadi, karena pengaruh faktor-faktor tersebut di ataslah, muncul siswa-siswa yang highachievers (berprestasi tinggi) dan under-achievers (berprestasi rendah) atau gagal sama sekali.

\section{Metode Penelitian}

Metodologi penelitian merupakan sekumpulan peraturan, kegiatan, dan prosedur yang digunakan oleh pelaku suatu disiplin ilmu. Metodologi juga merupakan analisis teoritis mengenai suatu cara atau metode. Penelitian merupakan suatu penyelidikan yang sistematis untuk meningkatkan sejumlah pengetahuan, juga merupakan suatu usaha yang sistematis dan terorganisasi untuk menyelidiki masalah tertentu yang memerlukan jawaban.

Desain penelitian ini adalah deskriptif kualitatif. Menurut Isaac $(1984 ; 46)$ penelitian deskriptif merupakana riset yang menjelaskan secara sistematis situasi dan fakta populasi tertentu secara faktual dan akurat. Lebih dari itu Arikunto $(1996 ; 244) \quad$ menyatakan bahwa kesimpulan akhir dalam studi deskriptif haruslah dalam bentuk katakata atau kalimat, bukan dalam bentuk angka-angka.

Sumber data primer ialah data yang secara langsung diakses oleh peneliti (Sugiono 2009, 308). Dalam studi ini, penulis mengambil data dari observasi kelas-kelas bahasa Inggris di Pondok Ta'mirul Islam. Baik guru maupun murid menjadi data obsevasi yang sangat penting untuk penelitian ini. 
Sugiyono (2009, 308) menyatakan bahwa sumber data sekunder ialah data yang secara tidak langsung digunakan oleh peneliti seperti data yang diambil dari dokumen-dokumen. Dalam penelitian ini, penulis mengambil sumber data dari bukubuku berikut terkait.

Penulis menggunakan metode observasi dan dokumen (hasil observasi dan wawancara dengan guru dan murid) untuk pengumpulan data. Dalam penelitian ini, dengan adanya metode observasi dan dokumentasi diharapakan dapat diketahui secara tepat model pembelajaran guru dan model belajar santri secara tepat dan akurat. Dengan metode ini diharapkan profile Pondok Putra Ta'mirul Islam dapat digambarkan secara gamblang. Untuk mendapatkan data penting ini sejak pertengahan bulan juli 2015 sampai awal oktober tahun 2015 peneliti melakukan observasi praktek semua guru bahasa Inggris di pondok putra Ta'mirul Islam Surakarta.

\section{Pembahasan}

Di Pondok Pesantren Ta'mirul Islam terdapat tujuh orang Pengajar Bahasa Inggris yaitu: Ust. Rachmat Faisal, S.Pd, Ust. Nur Rohmat, Ust. M. Nurrohim Maksum, Ust. Kholid Ramadanzi, Ust. Aziz Faizin, Ust. Tri Agus Santosa dan Ust. Ahsanul Fikri.

Semua pengajar bahasa Inggris di pondok putra tersebut adalah alumni Pondok Darrussalam Gontor, Ponorogo atau semua pesantren lain tetapi menerapkan model KMI atau Kulliyatul Mu'allimin Islam. Model atau sistim KMI ini bertujuan untuk mencetak tenaga-tenaga pengajar Islam yang disamping menguasai materimateri keislaman tapi juga secara skills atau ketrampilan mampu berbicara dan menulis secara lancar dua bahasa Asing yang dianggap sebagai "pakaian pondok" yaitu bahasa Arab dan bahasa Inggris.

$$
\text { Dalam kaitannya dengan }
$$
pengajaran bahasa Inggris di Pondok
Pesantren Ta'mirul Islam hal yang unik dan menarik yang bisa diamati adalah bahwa hanya satu pengajar yaitu Ust. Rachmat Faisal, S.Pd yang memiliki latar belakang pendidikan khusus kajian Bahasa Inggris. Namun, walaupun demikian ada rasa percaya diri yang besar pada setiap pengajar karena ketika mereka belajar di Gontor atau di Pondok pesantren lain yang berafiliasi atau mengikut pola Pondok Gontor yang disebut KMI tersebut mereka sudah terasah selama bertahun-tahun berbicara dan menulis dalam kedua bahasa asing tersebut.

Kemudian, berikut ini akan dipaparkan hasil observasi selama 10 (sepuluh) kali masuk ke kelas-kelas bahasa Inggris yang diampu ketujuh pengajar tersebut.

\section{Pengamatan Pembelajaran Guru 9 Juli 2015}

Kelas pertama yang diamati adalah kelas bahasa Inggris di kelas VI. Pengamatan ini dikerjakan pada hari kamis malam jam 20.00 tanggal 9 Juli 2015. Kelas malam ini berbeda dengan kelas yang lain karena suasananya lebih bersifat informal. Kelas tersebut di adakan di aula Pondok.Kelas malam tersebut diadakan setelah santri menjalankan sholat Isya' dan Tarawih dan diadakan dengan suasana yang santai.

Ust. Nur Rohmat sebagai salah satu pengajar senior di Pondok Ta'mirul Islam memiliki gaya mengajar yang santai tetapi mengena. Ust. Nur Rohmat memulai kegiatan awal pembelajaran dengan mengucapkan salam dan Good Evening, everyone. Malam itu Beliau menjelaskan sub materi Simple Past and Past Continuous. Dalam pembelajarannya diawali dengan menjelaskan serba serbi simple past dan past continuous berikut rumus dan contoh kalimat praktis sehari-hari. Santri, walaupun terkadang bercanda di antara teman, tetapi tetap fokus dan antusias dalam mengikuti proses belajar dan mengajar. 


\section{Agustus 2015}

Kelas kedua yang diamati adalah kelas bahasa Inggris di kelas II. Pengamatan ini dikerjakan pada hari selasa pagi jam 08.50-10.10 tanggal 25 Agustus 2015 di kelas II-C. Mulai tanggal ini peneliti diberi kesempatan oleh pengasuh Pondok untuk masuk ke kelas-kelas mulai dari kelas I sampai kelas VI. Kelas tersebut adalah kelas yang formal sebagaimana kelas-kelas yang lain. Mulai kelas I sampai III disebut Tsanawiyah sedangkan mulai kelas IV sampai VI disebut sebagai Ma'had Aly. Bagi santri yang latar belakangnya SMP atau Tsanawiyah di luar pondok jika mereka bergabung di Ma'had Aly yang selevel dengan tingkat Aliyah diadakan kelas takhasus untuk meng-upgrade atau kelas khusus agar mereka yang tidak terbiasa dengan pola KMI di Pondok Ta'mirul Islam bisa menyesuaikan dengan pola dan sistem yang sudah diterapkan dari kelas I. Kelas takhasus tersebut akan dipaparkan pada pengamatan tanggal 5 September oleh Ust. Kholid Ramadanzi.

Pembelajaran bahasa Inggris pada kelas II-C ini diampu oleh Ust. Aziz Faizin yang merupakan salah satu pengajar senior di Pondok Ta'mirul Islam memiliki penampilan yang rapi dengan memakai peci dan berdasi dan gaya mengajarnya yang bisa dikategorikan cukup tegas dan disiplin.

\section{September 2015}

Kelas ketiga yang diamati adalah kelas bahasa Inggris di kelas tiga. Pengamatan ini dikerjakan pada hari Rabu pagi jam 09.30-10.10 di kelas IIIC. Pembelajaran Bahasa Inggris pada kelas III-C ini diampu oleh Ust. M. Nurrohim Maksum (U) yang seperti halnya pengajar senior yang lain di Pondok Ta'mirul Islam yaitu Ust. Nur Rohmat atau Ust. Azis Faizin, ia memiliki penampilan yang rapi dengan memakai peci dan berdasi dan gaya mengajarnya yang bisa dikategorikan tegas, disiplin, dan berapi-api atau sangat bersemangat.
Hal ini bisa dilihat ketika pembelajaran diawali dengan mengucapkan salam dan menyapa siswa ataus antri dengan ungkapan formal spoken English dan ungkapan penyemangat di pagi hari dengan narasi sebagai berikut (U : Ust. M. Nur rohim Maksum, S : Siswa Kelas IIIC)

U : Assalamu'laikum warahmatullahi wabarakatuh!

S : Wa'alaikumsalam warahmatullahi wabarakatuh!

$\mathrm{U}:$ How are you today?

S : Fine, Thank you

$\mathrm{U}$ : How's life today?

$\mathrm{S}$ : Life is beautiful and powerful.

$\mathrm{U}$ : What is our lesson today?

$\mathrm{S}$ : Our Lesson today iiiissss Engliiiiiissssssh.

Sungguh sebuah model pembelajaran yang menarik dan unik. Pelajaran dimulai dengan kalimat yang penuh semangat yaitu Life is beautiful and powerful. Walaupun peneliti sudah memahami arti dan makna kalimat tersebut tetapi tetap di-cross check-kan ke siswa tentang apa yang mereka pahami dari kalimat tersebut. Beberapa di antara mereka mengatakan "Hidup itu indah dan penuh semangat". Sungguh merupakan sebuah penyemangatan awal yang baik dan memberi stimulus kepada siswa agar selalu punya semangat belajar dan adanya kebersamaan mengucapkan kalimat seperti Our Lesson today iiiissss Engliiiiiissssssh. Ini merupakan sebagian contoh dari efektifnya bi'ah luqhowiyyah atau lingkungan bahasa yang bertahun-tahun telah terwujud di pondok pesantren Takmirul Islam.

\section{September 2015}

Kelas keempat yang diamati adalah kelas bahasa Inggris di kelas enam. Pengamatan ini dikerjakan pada hari Sabtu pagi jam 07.30-08.10. Pembelajaran bahasa Inggris pada kelas VI ini diampu oleh Ust. Tri Agus Santosa yang seperti halnya pengajar senior yang lain di Pondok Ta'mirul Islam, memiliki penampilan yang rapi dengan memakai peci dan berpakaian 
batik seragam pengajar di Pondok Ta'mirul Islam. Gaya mengajar beliau mirip dengan Ust. Nur Rohmat yang bersifat kalem tetapi jelas dalam menerangkan materi. Kelas Bahasa Inggris pada tanggal 5 September 2015 tersebut memiliki submateri Passive Voice.

Selain kelas Ust. Tri Agus Santosa kelas kelima yang diamati pada hari yang sama adalah kelas bahasa Inggris di kelas VI. Pengamatan ini dikerjakan pada jam 10.10- 12.00 di kelas VI. Pembelajaran bahasa Inggris pada kelas ini diampu oleh Ust. Rachmat Faisal, S.Pd. Beliau adalah satusatunya pengajar senior yang khusus berlatar belakang pendidikan Bahasa Inggris. Kemudian, kelas keenam yang diamati adalah kelas Grammar yang diampu oleh Ust. Ahsanul Fikri. Pembelajaran tanggal 5 September 2015 ini diterapkan di kelas IIA dengan sub materi berjudul $W$-H Questions.

\section{September 2015}

Kelas ketujuh yang diamati adalah kelas Grammar yang diampu oleh Ust. Kholid Ramadanzi. Pembelajaran hari Ahad, tanggal 6 September 2015 ini diterapkan di kelas III TKS. Maksud dari singkatan TKS ialah takhasus atau pengkususan. Dari awal peneliti berpikir bahwa kelas dengan label TKS ini adalah kelas khusus anak-anak terpandai tetapi ternyata bukan demikian. Kelas dengan label TKS ini adalah kelas khusus bagi siswa yang latar belakangnya SMP/SLTP umum atau dari level Tsanawiyah yang bukan program KMI tetapi ingin melanjutkan ke level Aliyah atau Ma'had Aly di Pondok Pesantren Moderen Ta'mirul Islam.

Pertemuan pada hari Ahad pada tanggal 6 September ini diampu oleh Ust. Kholid Ramadanzi, seorang Ustadz muda alumni Pondok Ta'mirul Islam. Pada Pertemuan tanggal 6 September ini Ust. Kholid Ramadanzi hanya mengawasi dan membetulkan santri yang sedang presentasi materi dan sekaligus memberi pujian bagi yang benar jawabannya dan memberi hukuman pada yang salah jawabannya. Yang unik dan menarik dari model pembelajaran model punishment and reward ini terasa pola hubungan guru dan murid sangat akrab.

Setelah 40 menit pelajaran berlangsung di kelas III TKS, kemudian peneliti meminta izin kepada Ust. Kholid Ramadanzi untuk ikut mengamati di kelas selanjutnya, kelas pengamatan kedelapan yaitu kelas I TKS. Sebagaimana kelas III TKS, kelas ini adalah kelas khusus persiapan bagi santri yang dulunya dari SMP/SLTP/Tsanawiyah di luar Pondok Pesantren Ta'mirul Islam.

Pada pertemuan tanggal 6 September ini, peneliti sangat terkesan dengan model pembelajaran Ust. Kholid Ramadanzi dimana siswa mendapatkan drill yang lumayan intensif mencoba melancarkan memori alfabet bahasa Inggris dari huruf A sampai $\mathrm{Z}$ dan angka dalam bahasa Inggris dari bilangan kecil seperti 1, 2 dan 3 sampai jumlah puluhan, ratusan dan ribuan. Meskipun kelihatan sangat klasik dan tradisional tetapi metode ini terasa mengena karena tidak ada satupun siswa yang merasa canggung untuk mengucapkan English numbers and alphabets. Semua itu dikerjakan dengan berdiri penuh semangat dan berteriak-teriak.

\section{September 2015}

Kelas ke-sembilan yang diamati adalah kelas Reading 3 yang diampu oleh Ust. Nur Rohmat .Pembelajaran hari Senin tanggal 14 September 2015 ini diterapkan di kelas regular III B.Ust. Nur Rohmat sebagai salah satu pengajar senior di Pondok Ta'mirul Islam tidak seperti pengajar lain yang berapi-api atau penuh semangat seperti Ust. Kholid Ramadanzi atau Ust. Maksum. Ust. Nur Rohmat memiliki gaya mengajar yang lebih santai, banyak senyum tetapi mengena. 
Ust. Nur Rohmat memulai kegiatan awal pembelajaran dengan mengucapkan salam dan Good Morning, everyone. Pagi itu Beliau menjelaskan materi Reading-English Lesson 3 dengan sub materi berjudul Beautiful Days at Jogja. Materi ini walaupun menggunakan buku Reading tetapi pada hari itu lebih diarahkan membuat recount text yang menjelaskan proses berjalannya aktivitas.

Setelah 40 menit pelajaran berlangsung di kelas III B, kemudian peneliti meminta izin kepada Ust.Nur Rohmat untuk ikut mengamati di kelas selanjutnya, kelas pengamatan kesepuluh yaitu kelas III-A.Sebagaimana di kelas kelas III B Ust. Nur Rohmat di kelas ini Beliau menjelaskan materi Reading-English Lesson 3 dengan submateri berjudul Beautiful Days at Jogja. Materi ini pada hari itu lebih diarahkan membuat genre recount text yang menjelaskan proses berjalannya aktivitas.

Secara umum dalam pengamatan peneliti setelah masuk di sepuluh kelas yang diadakan pembelajaran Bahasa Inggris di dalamnya dapat disimpulkan bahwa terdapat strategi pembelajaran langsung dan menggunakan TeacherCentered Approach yang sangat diarahkan oleh guru. Metode yang cocok untuk strategi dan pendekatan ini antara lain: ceramah, tanya jawab, demonstrasi, latihan, dan drill. Strategi dan pendekatan ini diperjelas dengan model pembelajaran army method", yang mengedepankan kedisiplinan tinggi serta otoritas guru dan Direct Method atau metode langsung (thariqah mubasyarah) yang pertama kali dikembangkan oleh F.Gouin (19 801992) berdasarkan asumsi yang ada dalam proses berbahasa antara Ibu dan anak.

\section{Pengamatan Model Belajar Siswa}

Selain membuat pengamatan model pembelajaran tujuh orang pengajar Bahasa Inggris di Pondok Pesantren Putra Ta'mirul Islam Surakarta peneliti juga membuat pengamatan terhadap tanggapan dan keaktifan santri atau siswa selama pembelajaran Berlangsung. Selain mengamati peneliti di luar jam pelajaran juga bertanya dan berdiskusi dengan santri mengenai proses pembelajaran Bahasa Inggris yang telah didapatkan. Berikut ini dalah hasil pengamatan peneliti terhadap sepuluh kelas yang diajarkan Bahasa Inggris pada tanggal 9 Juli 2015, 25 Agustus 2015, 2 September 2015, 5 September 2015, 6 September 2015 dan 14 September 2015.

\section{Juli 2015}

Kelas pertama yang diamati adalah kelas Bahasa Inggris di kelas Enam. Pengamatan ini dikerjakan pada hari kamis malam jam 20.00 tanggal9 Juli 2015. Kelas malam hari ini cukup berbeda dengan kelas yang lain karena suasananya lebih bersifat informal. Kelas tersebut di adakan di aula Pondok.Kelas malam tersebut diadakan setelah santri menjalankan sholat Isya' dan Tarawih dan diadakan dengan suasana yang santai.Santri atau siswa walaupun terkadang bergurau di antara mereka tetapi tetap fokus dan antusias mengikuti pembelajaran.

Setelah selesainya proses pembelajaran yang 60 menit itu peneliti berkesempatan untuk berdialog dengan santri kelas enam bernama Rosyid Adi Nur Rohim. Dia bercerita betapa bersyukurnya dia bisa belajar di Pondok Pesantren Ta'mirul Islam karena dibandingkan dengan temanteman sekampungnya yang tidak belajar di pesantren dia merasakan suasana agama dan suasana belajar yang lebih baik.Sebagian teman-teman di desanya ada yang terkena efek pergaulan bebas dan sulit dinasehati orangtua.Mengenai pembelajaran baik Bahasa Inggris maupun bahasa Arab dia merasakan efektifitas model pembelajaran Direct Method ini karena adanya bi'ah lughowiyah atau "suasana bahasa".

\section{Agustus 2015}


Kelas kedua yang diamati adalah kelas bahasa Inggris di kelas II. Pengamatan ini dikerjakan pada hari selasa pagi jam 08.50-10.10 tanggal 25 Agustus 2015 di kelas II-C. Mulai tanggal ini peneliti diberi kesempatan oleh pengasuh Pondok untuk masuk ke kelas-kelas mulai dari kelas I sampai kelas VI. Kelas tersebut adalah kelas yang formal sebagaimana kelas-kelas yang lain.Mulai kelas I sampai III disebut Tsanawiyah sedangkan mulai kelas IV sampai VI disebut sebagai Ma'had Aly.

Pada tanggal 25 Agustus 2015 tersebut Ustadz/pengajar menjelaskan submateri Simple Present Tense. Dalam pembelajarannya diawali dengan menjelaskan serba serbi simple present tense berikut rumus dan contoh kalimat praktis sehari-hari. Para santri kelihatan antusias dan fokus dalam memperhatikan pengajaran guru dan satu hal yang menarik adalah kepandaian pengajar untuk mengarahkan siswa agar tetap fokus dengan satu per satu diberi pertanyaan dan langsung dikoreksi jika ada jawaban yang salah.

Saat melakukan pengamatan terhadap guru pengajar bahasa Inggris, yaitu Ust. Aziz Faizin, peneliti juga sempat berkenalan dengan siswa kelas II-C bernama Sannang Indra Rahmanto dan Muhammad Da'i Burhan. Saat itu peneliti mencoba kemampuan Bahasa Inggris siswa kelas II-C dengan bertanya dalam Bahasa Inggris, "When will this lesson ended?" (artinya dalam bahasa Indonesia, "Kapan pelajaran ini akan berakhir?". Sebenarnya peneliti sudah tahu jawabannya tetapi pertanyaan kepada Sannang Indra Rahmanto ini dimaksudkan untuk menguji kemampuan mereka dengan memberi pertanyaan spontan sehingga bisa diketahui jawaban siswa ini automatical atau tidak. Saat itu Sannang Indra Rahmanto agak terkaget tetapi kemudian bisa menjadi tenang dengan bertanya pada teman di sampingnya yaitu Muhammad Da'i
Burhan, "Fi ayyi sa'ah hadza darsa...." .Sungguh pengalaman yang menarik. Peneliti bertanya dalam bahasa Inggris tetapi Sannang Indra Rahmanto bertanya dalam Bahasa Arab kepada temannya.

\section{September 2015}

Kelas ketiga yang diamati adalah kelas bahasa Inggris di kelas tiga. Pengamatan ini dikerjakan pada hari Rabu pagi jam 09.30-10.10 di kelas IIIC. Pembelajaran Bahasa Inggris pada kelas III-C ini diampu oleh Ust. M. Nurrohim Maksum yang memiliki penampilan yang rapi dengan memakai peci dan berdasi dan gaya mengajarnya yang bisa dikategorikan tegas, disiplin, dan berapi-api atau sangat bersemangat. Hal ini bisa dilihat ketika pembelajaran diawali dengan mengucapkan salam dan menyapa siswa atau santri dengan ungkapan formal spoken English dan ungkapan penyemangat di pagi hari.

Dalam pengamatan Peneliti, ada sebagian siswa yang asal-asalan dan main-main dalam menjawab tetapi secara umum siswa bersemangat mengikuti pelajaran dari awal sampai akhir. Mungkin karena seperti yang dikatakan Ust. Sunardi Sujani bahwa berhasilnya pengajar di Pondok Ta'mirul Islam ialah bisa membuat siswa berteriak-teriak mengulang apa yang disampaikan oleh pengajar. Sehingga suasana "kegaduhan" pembelajaran bukan dianggap sebagai masalah tapi jusru stimulus secara umum agar ada semangat bersama untuk mencapai fluency atau kelancaran dan kebiasaan berbicara dan menulis dalam bahasa asing dalam hal ini adalah bahasa Inggris.

\section{September 2015}

Kelas keempat yang diamati adalah kelas bahasa Inggris di kelas VI. Pengamatan ini dikerjakan pada hari Sabtu pagi jam 07.30-08.10. Pembelajaran Bahasa Inggris pada kelas VI ini diampu oleh Ust. Tri Agus Santosa. Kelas Bahasa Inggris 
pada tanggal 5 September tersebut memiliki submateri Passive Voice. Materi ini diterangkan dengan gamblang dan siswa dituntun untuk membuat contoh berdasarkan rumus dan contoh passive voice yang telah dituliskan di papan tulis. Secara umum proses belajar dan mengajar Grammar pada hari itu berjalan normal dan lancar.

Menurut pengamatan peneliti, siswa kelas enam sudah sangat mapan dan tenang dalam menerima materi. Sepertinya gemblengan kedisiplinan dari kelas satu dan kelas lima telah berhasil secara behavioristik melatih mereka untuk fokus menerima pelajaran sehingga ini memudahkan pengajar untuk menyampaikan materi. Model army method yang banyak dikritik sudah tidak up to date atau ketinggalan zaman alias sudah lawas ternyata masih efektif dalam membentuk karaktek belajar siswa.

Selain kelas Ust. Tri Agus Santosa kelas kelima yang diamati pada hari yang sama adalah kelas bahasa Inggris di kelas VI. Pengamatan ini dikerjakan pada jam 10.10-12.00 di kelas VI. Pembelajaran Bahasa Inggris pada kelas ini diampu oleh Ust. Rachmat Faisal, S.Pd.

\section{September 2015}

Kelas ketujuh yang diamati adalah kelas Grammar yang diampu oleh Ust. Kholid Ramadanzi. Pembelajaran hari Ahad tanggal 6 September 2015 ini diterapkan di kelas III TKS. Maksud dari singkatan TKS ialah takhasus atau pengkususan. Dari awal peneliti berpikir bahwa kelas dengan label TKS ini adalah kelas khusus anak-anak terpandai tetapi ternyata bukan demikian. Kelas dengan label TKS ini adalah kelas khusus bagi siswa yang latarbelakangnya SMP/SLTP umum atau dari level Tsanawiyah yang bukan program KMI tetapi ingin melanjutkan ke level Aliyah atau Ma'had Aly di Pondok Pesantren Moderen Takmirul Islam.
Pada Pertemuan tanggal 6 September ini Ust. Kholid Ramadanzi hanya mengawasi dan membetulkan santri yang sedang presentasi materi dan sekaligus memberi pujian bagi yang benar jawabannya dan memberi hukuman pada yang salah jawabannya. Yang unik dan menarik dari model pembelajaran model punishment and reward ini terasa pola hubungan guru dan murid sangat akrab. Sehingga jika ada punishment atau hukuman berupa coretan spidol tidak permanen di pipi atau dagu santri tidak membuat dendam tapi justru membuat gelak tawa siswa yang dihukum juga temanteman yang melihatnya. Sebuah kondisi yang kondusif dan menyenangkan dan media penyesuaian yang baik buat siswa dari luar yang ingin melanjutkan di Ma'had Aly atau level Aliyah di Pondok Pesantren Ta'mirul Islam.

\section{September 2015}

Kelas kesembilan yang diamati adalah kelas Reading 3 yang diampu oleh Ust. Nur Rohmat .Pembelajaran hari Senin tanggal 14 September 2015 ini diterapkan di kelas regular III B. Ust. Nur Rohmat memulai kegiatan awal pembelajaran dengan mengucapkan salam dan "Good Morning, everyone”. Pagi itu Beliau menjelaskan materi Reading-English Lesson 3 dengan submateri berjudul Beautiful Days at Jogja.

Materi ini walaupun menggunakan buku Reading tetapi pada hari itu lebih diarahkan membuat recount text yang menjelaskan proses berjalannya aktivitas. Jadi selain menjelaskan materi secara singkat santri atau siswa diajarkan untuk bersama-sama membuat kalimat dan paragraf dengan pola recount text dengan judul Beautiful Days at Jogja. Dalam pengamatan peneliti, santri walaupun terkadang bercanda di antara teman tetapi tetap fokus dan antusias dalam mengikuti proses belajar dan mengajar.

Setelah 40 menit pelajaran berlangsung di kelas III B, kemudian 
peneliti meminta izin kepada Ust.Nur Rohmat untuk ikut mengamati di kelas selanjutnya, kelas pengamatan kesepuluh yaitu kelas III-A. Sebagaimana di kelas kelas III B Ust. Nur Rohmat di kelas ini Beliau menjelaskan materi Reading-English Lesson 3 dengan submateri berjudul Beautiful Days at Jogja. Materi ini pada hari itu lebih diarahkan membuat genre recount text yang menjelaskan proses berjalannya aktivitas.

Menurut pengamatan peneliti dalam pembelajaran hari Senin tanggal 14 September 2015 yang diterapkan di kelas regular III A dan III B oleh Ust. Nur Rohmat dapat dinyatakan bahwa setelah siswa atau santri telah mendapatkan penguasaan Vocabulary atau kosa kata yang cukup pada tahun pertama dan kedua maka mulai tahun ketiga barulah mereka belajar English Grammar atau tata bahasa Inggris dan juga mulai dikenalkan dengan genre atau jenis-jenis teks dalam bahasa Inggris. Hesitation removal atau penghilangan keragu-raguan dalam belajar sudah berjalan. Sesudah proses receptive atau pemerolehan bahasa berjalan efektif, baru diajarkan proses productive dalam keterampilan atau skills berbahasa asing.

\section{Daya Pendorong dan Penghambat dalam Proses Belajar Bahasa Inggris}

Dalam wawancara yang diadakan oleh peneliti kepada Ustadz Adhiem, putraUst. KH. Naharussurur (Pendiri dan Pimpinan pertama Pesantren Ta'mirul Islam Surakarta) didapatkan data penting tentang apa yang menjadi daya pendorong dan penghambat dalam proses belajar bahasa Inggris di Pondok Putra Pesantren Ta'mirul Islam Surakarta.

Daya pendorong

Daya Pendorong Proses Belajar Bahasa Inggris di Pondok Putra Pesantren Takmirul Islam Surakarta ialah adanya sarana, prasarana, bi'ah lughowiyyah atau suasana akan cukup memadai untuk memajukan santri untuk mampu berbicara dan menulis dalam bahasa Inggris.

Dua kegiatan penunjang selain di kelas yang berhasil diamati oleh peneliti adalah kegiatan latihan berpidato untuk semua santri atau siswa dan drill penguasaan vocabulary atau kosa kata setelah makan siang. Hal ini merupakan unsur penunjang kegiatan yang cukup efektif dalam mewujudkan tahap demi tahap language acquisition atau pemerolehan bahasa asing dalam hal ini adalah bahasa Inggris.

Kegiatan latihan berpidato untuk seluruh santri kecuali santri kelas 5 dan 6. Kegiatan ini bersifat mingguan dan hal ini merupakan unsur penunjang kegiatan yang cukup efektif dalam mewujudkan tahap demi tahap language acquisition atau pemerolehan bahasa asing dalam hal ini adalah bahasa Inggris. Pada hari Ahad, tanggal 6 September 2015, peneliti berkesempatan untuk melakukan pengamatan terhadap kegiatan latihan berpidato santri. Sungguh menarik melihat santri dari kelas satu sampai empat diarahkan oleh mentor atau pendamping mereka bukan dari ustadzustadz yang biasa mengajar bahasa Inggris tapi oleh kakak kelas mereka yang duduk di kelas 5 dan 6. Pola asahasih-asuh dari kakak kelas kepada adik kelasnya cukup efektif untuk membangkitkan dan membiasakan santri untuk percaya diri dan berani tampil berpidato dalam bahasa Inggris walaupun masih dalam bentuk pidato sederhana.

Kegiatan drill Penguasaan vocabulary atau kosa kata untuk seluruh santri kecuali santri kelas 5 dan 6. Kegiatan ini bersifat mingguan dan hal ini merupakan unsur penunjang kegiatan yang cukup efektif dalam mewujudkan tahap demi tahap language acquisition atau pemerolehan bahasa asing dalam hal ini adalah bahasa Inggris. 
Di Pondok Putra Ta'mirul Islam Surakarta, telah lama menjadi kebijakan pengasuh pondok agar setelah dua minggu Arabic Weeks maka setelah itu satu minggu English Week dan Alhamdulillah pada hari Sabtu, tanggal 5 September 2015, peneliti berkesempatan untuk melakukan pengamatan terhadap Kegiatan drill penguasaan vocabulary atau kosa kata.

\section{Daya penghambat}

Faktor penghambat utama dalam proses belajar bahasa Inggris di Pondok Putra Pesantren Ta'mirul Islam Surakarta ialah sikap santri yang menganggap biasa hukuman-hukuman yang diberikan. Ada kekhawatiran dari pihak pengasuh pondok dan pengajar jika hukuman itu bersifat hukuman fisik seperti dipukul akan menjadikan santri merasa dendam kepada pengajar atau senior yang memberi hukuman. Adanya hukuman untuk membentuk kedisiplinan seperti yang sekarang yang berjalan seperti disuruh berdiri panas-panas di siang hari dan berucap selama lima menit dengan kalimat, Hey, Boys, speak English! Hey, Boys, speak English! atau diberi kalung dari bahan kertas karton bertuliskan Let's speak English tidak memberikan efek jera kepada santri. Mereka menganggap biasa hukuman-hukuman tersebut. Padahal dari pihak orangtua sudah menyerahkan kepada pengasuh dan pengajar pondok untuk melatih dan mendidik santri terserah bagaimana cara pendidikannya.

Sebagaimana kualitas pendidikan di Gontor sekarang ini agak menurun dibandingkan dengan generasi awal karena bentuk-bentuk hukumannya kurang memberi efek jera karena takut santri menjadi dendam dengan pengajar dan senior-seniornya, demikian juga di pondok Takmirul ini dirasakan hukuman-hukuman yang ringan kurang memberi efek jera sehingga kedisiplinan kurang terbentuk dan hasil belajar yang diharapkan kurang maksimal.

\section{SIMPULAN}

Mengacu pada tiga hal yang telah dipaparkan dan dijelaskan sebelumnya mengenai model pembelajaran guru, model belajar santri, dan daya pendorong dan penghambat dalam proses belajar bahasa Inggris di Pondok Pesantren Putra Ta'mirul Islam Surakarta dapat disimpulkan sebagai berikut:

1. Secara umum dalam pengamatan peneliti setelah masuk di sepuluh kelas yang diadakan pembelajaran bahasa Inggris di dalamnya dapat disimpulkan bahwa terdapat strategi pembelajaran langsung dan menggunakan teacher-centered approach yang sangat diarahkan oleh guru.

2. Menurut pengamatan peneliti, model belajar santri atau siswa di Pondok Putra Ta'mirul Islam Surakarta menganut pola behavioristik yang menekankan pembiasaan dalam skills atau keterampilan berbahasa dengan pola army method yang mendisiplinkan siswa dengan pola punishment and reward. Pujian dan penghargaan bagi yang berhasil dan hukuman yang bersifat mendidik bagi yang gagal dalam proses belajar.

3. Daya pendorong proses belajar bahasa Inggris di Pondok Putra Pesantren Ta'mirul Islam Surakarta ialah adanya sarana, prasarana, bi'ah lughowiyyah atau suasana akan cukup memadai untuk memajukan santri untuk mampu berbicara dan menulis dalam bahasa Inggris. Sedangkan, faktor penghambat utama dalam proses belajar bahasa Inggris di Pondok Putra Pesantren Ta'mirul Islam Surakarta ialah sikap santri yang menganggap biasa hukumanhukuman yang diberikan. Ada kekhawatiran dari pihak pengasuh pondok dan pengajar jika hukuman itu bersifat hukuman fisik seperti dipukul akan menjadikan santri 
merasa dendam kepada pengajar atau senior yang memberi hukuman. Adanya hukuman untuk membentuk kedisiplinan seperti yang sekarang yang berjalan selama ini tidak memberikan efek jera kepada santri. Mereka menganggap biasa hukumanhukuman tersebut. Padahal dari pihak orangtua sudah menyerahkan kepada pengasuh dan pengajar Pondok untuk melatih dan mendidik santri terserah bagaimana cara pendidikannya.

\section{Daftar Pustaka}

Arikunto, Suharsimi. 1996. Prosedur Penelitian Suatu Pendekatan Praktek. Jakarta: Rineka Cipta

Chaplin, JP. 1958. Dictionary of Psychology. New York: Dell Publishing

Depdiknas. 2002. Kamus Besar Bahasa Indonesia. Jakarta: Balai Pustaka

Dick, W. \& L Cary. 1990. The Systematic Design of Instruction, Third Edition, New York: Harper Collins

Huda, Miftahul. 2013. Model-Model Pengajaran dan Pembelajaran: Isu-isu Metodis dan Paradigmatis. Yogyakarta: Pustaka Pelajar

Fatah, Abdul. 2011. Strategi Pondok Pesantren Attaqwa Putra Bekasi dalam Menerapkan Komunikasi Berbahasa Arab dan Inggris pada Santri. Jakarta: UIN Syarif Hidayatullah

Joyce, Bruce. Weil, Marshal. 1996. Models of Teaching. Boston: Allyn and Bacon.

Kemp, Jerrold E. 1977. Instructional Design: Plan for Unit and Course
Development. New York: Holt, Rinehart \& Winston.

Kurniawati, Erna Dwi. 2005. Metode Pengajaran Bahasa Arab dan Bahasa Inggris (Studi di Pesantren Putri Al Mawaddah Coper Jetis Ponorogo). Malang: UMM

Madjid, Nurcholish, 1997. Masyarakat Religius. Jakarta: Paramadina

Moleong, Lexy J. 2010. Metodologi Penelitian Kualitatif. Bandung: Rosdakarya.

Rais, Amien. 1987. Cakrawala Islam Antara Cita dan Fakta. Bandung: Mizan.

Reber, Arthur S. 1995. The Penguin Dictionary of Psychology. California: University of California

Rusman. 2010. Model-Model Pembelajaran: Mengembangkan Profesionalisme Guru. Jakarta: Rajawali Press

Subyakto, Sri Utari. 1992. Metodologi Pengajaran Bahasa. Jakarta; PT Gramedia Pustaka Utama

Soedjoko, Prasodjo. 1982. Profil Pesantren, Jakarta. Penerbit LP3ES

Stephen, Isaac and Michael William. 1982. Handbook in Research and Evaluation. San Diego: Edits Publishers

Sugiyono. 2006. Teknik Penelitian. Yogyakarta: Pines

Syah, Muhibbin. 2010. Psikologi Belajar. Jakarta: PT Raja Grafindo Persada

Wittig, Arno F. 1981. Psychology of Learning. New York: McGraw-Hill Book Company

Zamakhsyari, Dhofier. 1983. Tradisi Pesantren. Studi tentang Pandangan Hidup Kyai. Jakarta: LP3ES

Zamakhsyari, Dhofier. 1984 Tradisi Pesantren. Jakarta: LP3ES 